\title{
The Alpha and Omega of Images in Cronenberg’s Cinema
}

\author{
Marina Pellanda \\ University IUAV Of Venice
}

\begin{abstract}
Cronenberg's cinema astounds and confounds: Its images are the first virus to have penetrated the venereal system of the seventh art, despite its images being born well before the richness of the audiovisual media had imposed the redefinition of the medium and of the scopic regime. If every new medium is an extension of our body, as stated by McLuhan, and if every extension envisages somehow an amputation-just think of the transformation of Brundle into a fly in The Fly (1986) - then Cronenberg is the first threshold to cross in entering the great world mixing board that by now constitutes the audiovisual media system today. The Canadian director is an important tile in this narrative. In fact, if it is true that he does not waste time in wondering whether this multimedia cartography is good or bad_-just think of a film like eXistenZ (1999)—it is also true that when watching the images from his films one always feels the exciting sensation that cinema is still in its fundamental place, at the centre of the nervous system composed by the world of images.
\end{abstract}

Keywords: virus, boundary, tactile image, vision-centered

Despite being born well before the richness of the audio-visual media had imposed the redefinition of the medium and the scopic regime, the images created by Cronenberg do not suffer from proteophobia: ${ }^{1}$ They are not afraid of transmutation. As a matter of fact, the Canadian director was the first to impose an irreversible mutation of images, by inserting in cinema the genes that appear to be modifying the evolution of its modes of perception.

The utilitarian prostheses that one encounters in Cronenberg's cinema messianically anticipate the advent of the "new flesh."2 By acting like modern make-up, they produce real theatrical effects simultaneously with filming, as, for example, in the movie Videodrome (1982).

And yet, if Max Renn, by allowing a videotape to be inserted in his stomach, becomes an interesting metaphor of how the body of images will be modified by the evolution of modes of perception, reversibility too appears to be important for the Canadian director. Although never explicitly asserted, it is the main test that Cronenberg's image must overcome, as a biological mutant subject.

And yet, for example, the mobile videorecorder Max Renn is an imperfect mechanism. He is like a remote control out of control that does not entirely function the way it should. Although both Hal 9000 from 2001: Space Odyssey by Stanley Kubrick (1968) and the replicants from Blade Runner (1982) by Ridley Scott were afflicted by similar malfunctioning, ${ }^{3}$ with Cronenberg we face a clarity of observation capable of keeping at due distance the experience of the organic mutation of the image.

Planet Cronenberg is certainly all criss-crossed by the "demon" of mutation that, by acting indeed like a virus, manages to modify the structure of the images, to change them, to contaminate them.

Marina Pellanda, Adjunct Professor of History of Photography, Cinema and Media, Department of Design and Planning in Complex Environments, University IUAV Of Venice, Italy; main research fields: Relationship between Cinema and the Arts. 
The director foresees the future of the images to the point that he considers completely obsolete and even predictable many of the worlds that attempt to restore the richness of audio-visual media. However, in the end, the work of this film-maker fascinates even more because, as we will see, cinema still has its place in it: central and fundamental in the nervous system constituted by the world of images.

Cronenberg's images, then, are the first virus to contaminate the bloodstream of the seventh art. And this is the reason why the cartography of the aesthetics of cinema and of media must without doubt consider the work of this director as a fundamental topological node.

Cronenberg's images are always healthy carriers of the virus, in other words they contain in themselves that different element which connects the before and the after, the interior and the exterior, the visible and the invisible of the mutative process which characterizes the body-image in progress.

In Cronenberg's cinema, the focus is often on the body. It is for this reason that, in his films, to refer to the body-image not uncommonly means also to deal with a body. A body that, metaphorically, objectifies, differently or monstrously, an image. An image that, having already in itself the virus of mutation, links a judging and explaining gaze to body changes. However, such a gaze is also forced to self-reflection by having to expose itself.

In every film by Cronenberg, we are always the witnesses of a body trying to control itself by turning itself into a guinea pig; or a body that is searching for something different, and the difference is the virus contained within it. That body prepares itself (more or less voluntarily) to welcome the results, which can be unpredictable, monstrous, or totally self-destructive.

So Max Renn kills himself saying "Long live the new flesh!” (Videodrome); the teacher seer from The Dead Zone (1983) dies in the nonetheless successful attempt to modify a foreseen reality; in The Fly (1986), there is the obvious monstrosity of the scientist fly. On the other hand, the protagonists in Crash (1996) and eXistenZ (1999) remain suspended, the former in the apathetic wait for the decisive and final impact, the only thing capable of raising that emotion or that sense of existing he seems to have lost; the latter, instead, in an eternal circular escape, in search of elementary coordinates which can't be found: those that would allow them to delimit the dimensions of game and reality.

Let us move away from focusing on the body and go back to look at Cronenberg's images, addressing the problem in a different way. Hence, rather than observing it on the basis of the coefficient of truth according to which the cinematographic image is usually defined, let us look at it wondering "is this image healthy or viral." Cronenberg imposes an essentially different approach upon us, with Godard's permission. (Godard who, as we know, declared, referring to cinematographic images: “Ce n’est pas une image juste. C’est juste une image.”4) And this because the filmmaker, watching the phenomena and beings which populate his films with a good, clinical if not surgical, eye, transforms his cinema into a laboratory for experiments. In the sense that, the director parasitizes, in other words infects, every image of his with a virus that, reacting like any biological virus, not only spoils it, but even destroys it from the inside using, just like if it were a real biological virus, the genetic code of his "host."

Cronenberg then, unlike Godard, seeks l'image juste, which is an image that, as visual explanation of its viral contamination, seems to be the answer of the Canadian director to Deleuze and his The Time-Image. As a matter of fact, through his viruses Cronenberg continually tries to pierce the culture of the image characterized by Deleuze as a "cliché culture" $(1989,200){ }^{5}$ 
It is a piercing that the Canadian director does not perform as a gratuitous provocation, but as one of the most penetrating ways to single out the gaze, which then becomes the seismograph or rather the radar that anticipates the mutation of the world melting pot of the media.

Cronenberg's cinema is a metaphor of the audio-visual media system in simultaneity, because it lives on something different, a malfunction, an anomaly, a virus that triggers a mutative process, by acting contagiously. By putting into play completely heterogeneous elements, this process creates combinations that can seem interregna against nature.

However, according to Deleuze and Guattari (Body without Organs), Nature "only evolves like this, against itself" (190). ${ }^{6}$ Hence, all the transmutations featured in Cronenberg's films are inseparable from the mutant character, from the virus. They do not only assail people but also, more generally, everything made corporeal by the director-from the semi-organic game-pod of eXistenZ, to the insect typewriters of Naked Lunch (1991) via the pulsating screens and the gasping videotapes of Videodrome.

But the most interesting mutative-viral process is the one in which Cronenberg places the viewer in the same hallucinatory state as his characters. It is a hallucinatory state that assails the viewer with a material image to the point of succeeding in transforming the eye and the ear into hypertrophic organs forced to work by synaesthesia. By so doing, it makes the planes of reality slide from the film to the viewer seamlessly, long before virtual reality had been talked about.

Certainly, Cronenberg's virus should be held accountable for taking one of the first steps towards shifting the limits of the cinematographic experience in favour of an impact that allows and has allowed the Canadian director to expand our sensorial capacities by reconfiguring the viewer's visual experience, yet without riding the airwaves like an electronic pirate.

Cronenberg shifts the limit of the perceptive experience of cinema (which must deal with a certain nostalgia for its origins only if nostalgia should pertain to the global melting pot of today's media) because it is simultaneously the virtual point of conjunction between these two extremes, but also, at the same time, the vanishing point: a vanishing point shaped most of the time as the impossible passage through the evangelical "eye of the needle."

The Mantle twins in Dead Ringers (1988) build monstrous surgical instruments to operate on mutant women, contemporising the bone thrown in the air by a monkey at the end of the first prehistoric scene in 2001: Space Odyssey (1968), by Kubrick. They are considered handsome and interesting by the art world and "evidence of a sick mind" according to the scientific community, but also a metaphor of how the lucid madness, which nowadays seems to pervade the world of media, can also be "a flower of evil."

Also in Naked Lunch, Cronenberg seems very mindful of limit, and as a matter of fact, the second motto of the film is a warning: "there is one Mark (a scar) you cannot beat: the Mark inside.” And since to break a mark also means to beat a record, with these words the Canadian director alerts us by trying to protect us from the long sequence of inner scars which are the sign of the life of the image.

Cronenberg speaks about "inner scars," McLuhan states that "every new medium is an extension of our body and every extension somehow envisages an amputation” $(2001,90){ }^{7}$ Therefore, if from an amputation a scar originates, there Cronenberg and McLuhan intersect. And yet Cronenberg, with respect to McLuhan, experiences the visible in the same way as St Thomas: Just like his characters and with them, he wants to touch to believe- the Mantle Twins are once again the more obvious metaphor of the tactile image. In fact, according to Cronenberg, the two gynaecologists do not see, they touch, appealing to the sense that perhaps is the only one that cannot be translated cinematographically. 
Also Bill Lee in Naked Lunch has to insert his hands into the entrails of the typewriter in order to write-and if this is the kind of experience through which his characters lose themselves and die from it, the director instead survives. And Cronenberg survives because in his film aesthetics, the image is material and tactile, meaning that as a carrier of constructive possibility, it is permanently unstable.

By creating the tactile image, the Canadian director educates the eye to overcome the oculocentric paradigm, working by synaesthesia.

For Johnny Smith in Dead Zone, every human being by now risks being nothing but a touchscreen: One just has to touch it lightly to have the chance to travel forward or backwards in the pre-programmed software of one's personal biography. One projects oneself inside it visualizing situations as in virtual reality. For this character, as for blind people, the sense of touch becomes an instrument of decoding the world by activating a hypertropic vision. It is by working by synaesthesia that this vision succeeds in opening the rhizomatic trajectories of an endless journey of the gaze.

So we can state that Cronenberg's images anticipate the global melting pot of the media which surrounds us today, by showing us how technology is changing not only our mind and our perceptive system but also, and above all, our body. In fact, Cronenberg states in an interview to Serge Grümberg: "Cinema for me is something tactile. It is not just visual” $(2005,170) .{ }^{8}$ Also he does not waste time wondering whether this new multimedia cartography is good or bad, but still presents us with images in which one always perceives the exciting sensation that cinema is still in its fundamental place, at the centre of a nervous system constituted by a world of images.

As a matter of fact, if every work by Cronenberg forces cinema to recognize itself in mutation, that is a change by which cinema reinvents itself from time to time, in specific cases producing considerable exchanges, cameos, and transitions which are in no way neutral, also when the desire to impose an appearance of normality is certainly always present in his poetics, despite everything. Hence if, for Cronenberg, cinema must first and foremost transgress its (presumed) language and exceed it by decoding and re-codifying itself in a sort of desirable nomadism, the director plays along, to put it in Serge Grümberg's words, "like a cheat” $(2005,175){ }^{9}$ In his hands, indeed, the re-writing of the genetic code of the Seventh Art is always also an erroneous enunciation, because it is never radical, but rather it is ambiguous, like the steaks which tastes weird, a little artificial, the steak that Veronica Quaife samples in The Fly to do the protagonist a favour.

Cronenberg is a very interesting player because, in the attempt to baffle the viewer, at a certain point, like Pikul/Jude Law in eXistenZ, he pauses the game. Hence, those that earlier were objective parameters of mutation, in his last films become variables of human psyche. One just has to think about the opening credits in Spider (2002), in which inkblots of the Rorschach test dominate the background. They make cinema a fundamental and dominant arena in the global melting pot of the media, by showing how an image, that wants to reinvent itself artistically at all costs, could also end up falling prey to itself, "fly of itself" one could say referring to Spider but also to A History of Violence (2005) and to A Dangerous Method (2011).

\section{Notes}

1. The various identities that Proteus assumes, for the purpose of evading the grip of Ulysses, are aimed at achieving an invisibility that makes him invulnerable. Proteus, the soothsayer who knows the past and the future, does not defend himself by fleeing but exposing himself in plain sight and also making himself invisible to those who threaten his power. The story of Proteus, 
the myth of metamorphic identity as a defense, is narrated in the fourth book of Homer's Odyssey and also in the Georgics of Virgil.

2. In Videodrome, "the new flesh" is the fusion between mechanics and the human body and, to be credible, this hyper-realistic situation shown by Cronenberg, must have real bases. Through terror and then the acceptance of "the new flesh," Cronenberg traces a hallucinatory path that redefines, in the sphere of the director's new philosophy, a new concept of reality and fantasy.

3. In Blade Runner, the replicants created by the Tyrell Corporation are organic androids designed to be as similar as possible to humans, but superior to humans in their physical abilities and with an intelligence equal to that of the genetic engineers who created them. Over time, the replicants can develop their own emotions and this is the reason why their creators, to endow them with a lifespan of only four years, have triggered in them a malfunction. Instead Hal 9000, the super computer of the spaceship created by Kubrick in 2001: A space Odyssey, seems unable to make mistakes but yet commits one, becoming unreliable for the crew of the spaceship. For this reason Hal 9000 is turned off while, being almost human, he implores the astronaut who is deactivating him to stop.

4. Le Vent d'est, Jean-Luc Godard, 1970.

5. Gilles Deleuze, Cinema 2: The Time-Image, University of Minnesota Press, Minneapolis, 1989, 200.

6. Gilles Deleuze, Felix Guattari, Anti Oedipus: Capitalism and Schizophrenia, Peguin Classics, London, 190.

7. Marshall McLuhan, The Medium Is the Messag, Gingko Press, Berkeley, 2001, 90.

8. Serge Grünberg, David Cronenberg: Interviews with Serge Grünberg, Plexus Publishing, New York, 2005, 170.

9. Serge Grünberg, David Cronenberg: Interviews with Serge Grünberg, Plexus Publishing, New York, 2005, 175.

\section{Works Cited}

Gilles, Deleuze. Cinema 2: The Time-Image. Minneapolis: University of Minnesota Press, 1989.

Gilles Deleuze and Felix Guattari. Anti Oedipus: Capitalism and Schizophrenia. London: Peguin Classics, 1977.

Serge Gründberg. Interviews with Serge Gründberg. New York: Plexus Publishing, 2005.

Marshall McLuhan. The Medium Is the Messag. Berkeley: Gingko Press, 2001.

David Cronenberg. Videodrome. Canada, 1982.

---. The Dead Zone. USA, 1983.

---. The Fly. USA, 1986.

---. Dead Ringers. Canada, USA, 1988.

---. Crash. Canada, United Kingdom, 1996.

---. Naked Lunch. Canada, United Kingdom, Japan, 1991.

---. eXistenZ. Canada, United Kingdom, 1999.

---. Spider. Canada, United Kingdom, 2002.

---. A History of Violence. 2005.

---. A Dangerous Method. France, Canada, United Kingdom, Germany, Switzerland, 2011.

Jean-Luc Godard. Le Vent d'est. France, 1970.

Stanley Kubrick. 2001: A Space Odissey. USA, United Kingdom, 1968.

Riudley Scott. Blade Runner. USA, 1982. 